\title{
EMOTIONALIZATION IN NEW TELEVISION FORMATS OF SCIENCE POPULARIZATION
}

\author{
Margarida Bassols, Anna Cros, and Anna M. Torrent
}

\begin{abstract}
The fierce struggle for television audiences is greatest when the content shown is not strictly entertainment, such as, for example, when specialized knowledge is brought to a wide audience. However, the appearance of new television formats has enabled scientific and technical contents to be brought closer to an unprepared and very diverse audience. What resources do these programs use to achieve this? Is emotionalization, which is increasingly dominant in the media, an important strategy in programs that seek to spread scientific knowledge among the general public? Do they use the plurilocutionary nature of their discourse to promote understanding of the contents and to capture the viewers' attention? Our research, which forms part of a broader study of new television formats and the communication of knowledge, is the first study on the discourse of the mediatization of knowledge in Spain. The topic is of particular interest because it coincides with the production of innovative television formats that endeavor to capture the interest of sections of the population that usually do not access this type of content. They have an important social function since, as Semir (2011: 19) points out, the knowledge of the world they promote reduces the fear generated in human beings by that which is opaque or unknown, thereby increasing the ability to make decisions and increasing efficiency.

Through the linguistic analysis of the statements uttered by the diverse voices of a popular communication program, Quèquicom (Whatwhohow), we will determine which emotions are more present in the program and, therefore, contribute towards its communicative success, and which speakers (presenters, experts or affected individuals) use them more. Determining the resources leading to the success of this program can provide effective tools for other programs with very diverse aims. Studies of this type in Spain have focused on the press but very little on television. This study forms part of a wider research project on new television formats and the communication of knowledge to different audiences and diverse levels of specialization. It has been proven that emotions join together to provide a dramatic progression, based on the tension-relaxation binomial, a progression that holds the audience's interest, in a similar manner to dramatic fiction programs. Moreover, the emotions can be examined in three ways: they can be referred to as a fact in the reality being narrated, expressed by the speakers or triggered in the audience. Lastly, it was also observed that the emotional charge that justifies the presence of affected individuals or witnesses in the majority of television programs spreads to the voices of the presenters themselves. The transmission of emotions is almost as important as that of knowledge.
\end{abstract}

Keywords: Media discourse; Television; Popularization; Emotions.

\section{Introduction}

Currently, specialized literature tends to consider scientific communication (or scientific 
vulgarization or popularization, according to authors and traditions) as a process providing individuals with the results of scientific research, rendering world phenomena comprehensible and raising debates on a social topic (Jacobi 1999; Myers 2003; Calsamiglia and López Ferrero 2003; Calsamiglia and Van Dijk 2004; Moirand 2007; Charaudeau 2008).

When the scientific communication discourse occurs through non-specialized mass media, it adopts characteristics that lead us to discuss, in accordance with (Charaudeau 2008), "scientific mediatization discourse". It is a hybrid type that combines aims that are informative, argumentative, didactic and attention-seeking. Therefore, although it uses the knowledge created by scientists as a benchmark, this knowledge is transformed in a discourse, constructed by the media, and often removed from the discipline to which it pertains; either because it deals with topics of a crosssectoral nature, or because it seeks to raise awareness in a recreational manner (towards specialized knowledge with diverse aims), in such a way that none of the discourses of the discipline in question can be used as a base.

Television communication programs fulfill a democratic right of citizens, which must provide them with the necessary information about their living conditions and their social environment so that they can form a well-founded opinion. It is no longer about explaining the scientific facts, but of showing the social implications. The traditional format of documentaries, direct antecedents of this type of television program, has evolved, thanks to new television resources and the aspiration to reach the maximum number of viewers possible. Information and entertainment come together to attract the audience.

The study we present is based on the analysis of three episodes of Quèquicom, a knowledge mediatization program broadcast weekly since 2006, at prime time and for 25 minutes, by Televisió de Catalunya; a public channel in Spain broadcasting in Catalan, founded in 1983. In a previous study of this same program (Cros et al. 2012), we demonstrated that the identities represented by the voices that appear were fundamentally constructed on the basis of discourse strategies that legitimize and give authority to the participants. The results of the research showed that the strategies most used by all the voices were the emotionalizing strategies (emotional engagement), which enables us to conclude that they comprise one of the most important resources to try to attract an audience.

Based on this previous study, the objective of this research is to analyze the use of emotions, through the linguistic analysis of the statements uttered by the diverse voices in the program analyzed, contextualizing it with observations referring to the visual and musical language accompanying them, in the analyzed episodes from the knowledge mediatization television program. The emotions that are most present in the program and, therefore, contribute towards its communicative success will be shown, as well as which speakers (presenters, experts or affected individuals) use them more. Deciphering the resources leading to the success of a program of this type can be applied to other programs with communicative objectives aimed at essentially general audiences.

The fact that the subject of this research, the program Quèquicom, has a higher audience level than the average of other television programs with similar content which has led to it being guaranteed a slot on the small screen for years - allows us to assume that it selects resources that are interesting, relevant and suitable to attract the viewers' attention and to increase their empathy towards them. For this reason we 
selected this program and seek to demonstrate the hypothesis that the degree of emotionalization of the contents is a key tool in this proximity to the viewer, even in programs like this one, which by nature has traditionally demanded a high degree of objectivity and personal distance.

\section{Theoretical framework}

\subsection{Television emotions}

Emotions appear especially in the narrative sequences of multiple media formats. Evidently the most emotion-filled programs are those entertainment programs that contain narration, such as sitcoms, television series and talk-shows. But emotionalization has started to gain ground in recent years, and, consequently, it occupies an important place in other completely or partially narrated "serious" programs, such as informative and educational programs - news, documentaries, docudramas; knowledge communication, specialized subject matter...- , in the example with which the expert explains a theory or establishes an argument, in a witness's version, in a victim's story... Konijn \& Holt (2011: 37) observe that "nowadays the borders between entertainment, news as well as information fare become blurred"; and they apply Frijda's "law of concern" (1988: 275) to media emotions - "Emotions arise in response to events that are important to the individual's goals, motives or concerns"since, according to these authors, emotions highlight " what is relevant to us, such as a threat or a reward" and can give the program a status of reality, based on the cognitive distortion of "If I feel, it must be real".

Diverse researchers have analyzed the presence of emotional content in a media message. Thus, Friestad \& Thorson (1986), using advertisements as a base, speak of neutral messages (with little emotional content), positive messages (with positive events and images), negative messages (with negative events and images) and poignant messages (with a mixture of positive and negative events and images). Other researchers, such as Nabi et al. (2008) and Ewoldsen et al. (2004), compare emotional messages with non-emotional messages that deal with serious topics, focusing on the verbal, iconic and auditory elements they contain, and observe that the former are designed to cause fear, while the latter are not. For their part, Lang \& Ewoldsen (2011) propose operational definitions of the emotional content, based on the presence of certain audio-visual codes, which mean that the message appears globally as positive or negative, and with a low, medium or high level of arousal.

For some specialists (Scherer 1998; Unz 2011), the emotions developed during the receipt of media products are processed in a similar way to real emotions. They refer to culturally-shared objectives, standards and values, and thus involve a multitude of people, who, as pointed out by Schwab \& Schwender (2011), are mainly interested in news that talks of threats to life, to physical integrity or to the delicate social balance. The messages that are focused on these topics tend to have a high emotional element, which makes the recipients feel more interested in keeping the status quo than in getting to the bottom of the information (Unz \& Schwab 2004). 


\subsubsection{Dimensions of media emotions}

Several lines of research have studied the dimensions of media emotions in depth: $a$ ) the typology (Lazarus 1966; Russell 1980; Ortony, Clore and Collins 1988; Galati et al. $1998) ; b$ ) the degree of emotional relation established between the viewer and the television message (Scherer 1988; Konjin \& Holt 2011); c) the viewer's motivation to watch a certain emotionalizing program, such as to manage their mood (Zillmann 1988; Bryant \& Zillmann 1994; Knobloch 2003), to obtain hedonic or eudaimonic gratifications (Oliver \& Raney 2011), or to use it as a cathartic resource (Berger 1962; Stotland 1968; Oliver \& Woole 2011); and $d$ ) the effect that this type of program can have on the viewer, so that it is more attractive to them, more memorable or even more plausible (Konijn \& Holt 2011; Unz 2011); driving them towards a distorted version of reality (Gerbner et al. 1986; Gerbner et al. 1994; Gerbner 1998), or involving them emotionally with real or fictitious characters (Zillmann \& Cantor 1977; Bryant \& Zillmann 1994; Raney 2011).

a) As regards the typology of emotions, there are different proposals, although there is some consensus on the most basic ones: Anger, anxiety, sadness and joy. However, the list can be lengthened: Some authors, such as Lazarus $(1966,1993)$, speak of 15 emotions, while Ortony, Clore and Collins (1988), refer to 22. The larger number is obtained by combining, for example, the four basic emotions to obtain "secondary" ones, grouping them around feelings of satisfaction, dissatisfaction, wellbeing and discomfort. Russell's proposal (1980) includes emotions considering two dimensions: Valence, the essential duality of pleasure/dissatisfaction, involving positive and negative experiences, and the arousal or excitement level, to achieve a wide emotional range, from tranquility to activation. Moreover, Galati et al. (1998) classified emotions according to the involvement of the person in the environment: Feelings of strength, superiority and control, or feelings of weakness, inferiority and lack of control in a situation.

b) With respect to the type of message and the emotion that can be provoked in the recipient, Scherer (1988) distinguishes three main types of media emotions: Induced, contagious and empathetic emotions. The induced emotions, also called "egoemotions", are experienced by the viewer during their exposure to a non-emotional media message (for example, an interview about economics); however, it does provoke emotion in them because in their assessment of the program they discover objectives, standards, values, etc., that they share or abhor. The contagious emotions, also called "co-emotions", are experienced by the recipient when they see the emotional behavior of the media person (laughing, crying...) and they automatically imitate them, without knowing what provoked it. Empathetic emotions are those experienced by the recipient who experiences the emotions of the media person intensely. That is, although the recipient is not directly affected, they try to follow or imagine the process and the assessment that leads them to be moved, and this is why they feel a similar emotion. This empathetic co-experience is one of the richest and most peculiar experiences of media emotions, and has been examined by other authors, such as Konjin \& Holt (2011), when they discuss multi-level emotions or metaemotions - as opposed to simple emotions (joy, anxiety, fear...) -, since they conceptualize emotions and thoughts about emotions.

c) Considering the viewer's motivation to watch a television program, the main 
drive is entertainment; in other words, to have a good time and escape the routine of everyday life. But they also want to satisfy emotional needs, as explained by the theories summarized below: The mood management theory, the gratification theory, and the catharsis theory.

- Mood management theory (Zillmann 1988; Bryant \& Zilmann 1994; Knobloch 2003) states that mood is a fundamental factor in selective exposure to the media. This means that people choose to watch certain programs (news, documentaries, comedies, tragedies, music, sports...) to regulate their mood, i.e. to eliminate or at least reduce negative moods and perpetuate or maximize positive moods. The recipient is thus moved by a hedonistic proposal. If they remember that, on an occasion, a program provoked an emotionally beneficial effect in them, it is likely that they will return to it as a stimulation measure each time their mood is in a similar circumstance. The gratification that the recipient experiences stems above all from the nature of the selected program, but also from the regulation of the excitement or relaxation that they obtain from watching it: Overcoming these lows and depressions or tensions and passions, respectively. For other researchers, such as Schmitz \& Lewandrowski (1993), this correspondence does not always occur, and the relation between television and mood unrest may be due, for example, to the bad conscience viewers have at times for wasting free time watching futile programs.

- Gratification theory (Oliver \& Raney 2008; Oliver \& Wooley 2011) focuses on the type of benefit the viewer hopes to obtain from media emotions. When they choose a television program, they do so with the aim of enjoying the entertainment it affords them and also the gratification it will presumably provide: Hedonic or eudaimonic gratification. Hedonic gratification is connected with pleasure, happiness and satisfaction, provided in particular by genres such as sitcoms, action films, comedies and competitions. The recipient watches these programs that provoke positive emotions to distract and enjoy themselves, with the main motivation of entertaining themselves, forgetting about problems and escaping from reality. On the contrary, eudaimonic gratification is connected with the quest for self-development, and the recipient aspires to obtain it through emotions experienced in news or educational programs, in which they seek, as well as entertainment, a deeper vision of the human condition, which satisfies the feelings of "psychological well-being", such as awareness of personal growth, self-acceptance, or searching for the meaning of life.

- Catharsis theory (Berger 1962; Stotland 1969; Oliver \& Wooley 2011) is related with the gratification theory and responds to the paradox that tragic stories are chosen by the viewer because they can generate positive emotional experiences. By means of the concept of catharsis, which appears in Aristotle's Poetics, this theory maintains that the negative emotions experienced by the participants on-screen provoke excitement and a mixture of fear and compassion in the viewer. But when these effects are "purified", they become a pleasant relief for them, because they feel transformed by a profound vital experience, and gratified by the vision of the human condition that they have achieved. In other words, they have come close to true happiness (eudaimonia, by Aristotle) which implies self-realization and personal development. The cathartic function of tragic entertainment has been called into question by Zillmann (1998), who disagrees that the expression of sadness or crying can reduce the recipient's feeling of sadness. On the contrary, Miceli \& Castelfranchi (2003) consider that it is the tension accompanying the inhibition of the emotional expression that really reduces with crying.

d) As regards the effects that the emotionalizing content of the programs can 
have on the recipient, we highlight the theory that defends their memorizing action, the cultivation theory and the affective disposition theory.

- Both Konijn \& Holt (2011) and Unz (2011) defend the role of emotions in the processing and memorizing of the message. Thus, they consider that media emotions do not obstruct the comprehension of the message, but rather, on the contrary, emotional situations - a victim's tears, for example - , far from being "unwanted noise" attract the recipients' attention, are relevant signifiers that help in the in-depth processing of the information, and, therefore, facilitate the memorizing of the media message. Lang, Bolls, Potter and Kawahara (1999) do not share this view, and maintain that if the excitement provoked by the emotion is too strong, it impedes the recognition of the message and its memory in such a way that it is unlikely that it will be stored properly in the memory.

- Cultivation theory (Gerbner et al. 1986; Gerbner et al. 1994; Gerbner 1998), supports the importance of the mediation and symbolical function of television in the cultural context in which it is broadcast. In this regard, it considers that television can make the recipient change their perception of reality if they watch it over a prolonged period of time, and, in particular - given the violence of many television messages -, may make them acquire an overly aggressive view of the real world adapted to that provided by the screen. The "mean world syndrome" makes reality be perceived as a jungle full of dangers and egoism, to the point that it can alter the psychosocial health of the recipient, i.e., their values, their beliefs and their attitudes. Although the cultivation theory puts the maximum emphasis on the consumption of violence and its effects, it also takes into consideration other negative stereotypes shown by the television, such as the image of women, marriage or work. The main critics of Gerbner's theory argue that an individual's attitudes are influenced by television, but also by other factors that are as or more important: Experiences, degree of education, socio-economic status...(BoydBarret \& Braham 1987); and also that exacerbated television violence is typical of North-American television, but not of television from other countries (Condry 1989).

- Affective disposition theory (Zillmann \& Cantor 1972, 1977; Zillmann 1991; Zillmann \& Bryant 1994; Raney 2006, 2011), maintains that the emotions experienced by the recipient are related to the emotional filiation they establish with the media characters, after having made a moral judgment about the correctness or incorrectness of their behavior. Thus, the-viewer empathizes with the hero - wishing him success and being happy when this occurs, in the same way hoping that he will not fail, and being sad when this happens. Yet the viewer feels the opposite emotions towards the evil character, that is, wishing him to fail and being happy when this occurs, and, on the contrary, feeling sad when the villain triumphs. The viewer is even willing to "widen" the limits of what is morally acceptable in the behavior of the favoured character. The expectations (desires and fears) of conflict resolution and resolution itself is what produces a viewer's joy or sadness. As Vorderer \& Knobloch (2000) and Zillmann (1996) observe, during the narrative process, these expectations become "suspense", associated with anxiety, when the viewer does not know exactly what will happen in the story that has started, but anticipates and fears that adverse things will happen to the hero, and that favorable things will happen to the evil character. This uncertainty provokes a negative emotional stimulation that the viewer will only overcome if the outcome is that which is desired.

Despite their differences, all these theories confirm the central role of emotions in media programs, which, in the end, enrich people's personal and social lives and help 
them to make decisions in relevant situations (Cosmides \& Tooby 2000; Fredrickson 1998). Media producers use emotionalizing content to satisfy the desires of the target audience and to ensure that the programs are accepted. As stated by Schwab \& Swender (2011: 21) "emotional media content fits like a key in the lock of the evolved emotional mechanism of the media user or recipient".

\subsubsection{Words, images, music}

If we focus on television emotions, which, as we have stated, mainly appear in narrative programs or in narrative sequences of other types of programs (and at times also in the description included), we must not underestimate the role played by the images, music and words. All three elements form part of the audiovisual semiotics and, therefore, it is logical that the emotional content is evoked in three groups.

It is certain that, as stated by Turner (2011), images and music amplify the emotion of the message and highlight the positive or negative charge that it wants to transmit. However, if we believe in the unity of the multimodal message, as Van Leeuwen does - who argues that there is always "one content form", even though it manifests itself "in different expression forms" - we will agree that the three groups are equally responsible for generating emotions, since each of them contributes to a joint, unique and very powerful emotional effect.

With respect to the relation between music and images, Casetti \& de Chio (1991), Carmona (1993) and Chaume (2004) observe four types of audio effects in the media, especially in the television: Structure (characterizing music of a program and of the different parts of a program), speech accompaniment (music that accompanies or intensifies the content of a speech), silence (background or intensifying) and noise (background or intensifying).

Authors such as Lang \& Ewoldsen (2011) focus on the media context where the message is located - in other words, the setting - to discuss its "emotional content", which is considered to be positive content if it contains positive expressions of emotion (laughing, smiling), positive locations and things (pretty beaches, eating...), and positive events and actions (sex, parties, awards...); while it is considered to be negative content, if it contains negative expressions of emotions (crying, shouting...); negative locations and things (cemeteries, prisons, blood...), and negative events and actions (funerals, fighting...). Words, images and sounds, therefore, make up an emotionally positive or negative message, which, in addition, can be not very exciting, quite exciting or very exciting, and can provoke expectations of serious and imminent threats or of equally close big opportunities.

It is clear that the combination of the different semiotics and the setting, with the aim of emphasizing an emotion as much as possible, increases the probability of obtaining an emotional response from the audience.

\section{Methodological framework}

\subsection{Corpus}

As mentioned above, our study is based on the analysis of three episodes of Quèquicom. 
The selection of this particular program, out of all the communication programs, is due to the audience success it has and the period of time during which it has been broadcast. It has broadcast more than 200 episodes. In 2011 it was selected as the most popular scientific program in Spain. It also received the Zapping Award as the best cultural program voted by the viewers. ${ }^{1}$ It focuses on scientific and technical topics that may be useful to the audience. In addition, it seeks to encourage communication between the scientific world and citizens, as defended on its webpage. However, it is not an educational program addressed to a learned audience, but rather, an attractive and interesting program for a lay audience that has concerns about the world. As regards the interest it arouses in the audience, it is not too daring to think that this is related to the emotionalization that its episodes contain.

We chose three episodes: 'The Bullet of Addiction' (25 June 2008), 'In the Mother's Womb' (15 October 2008) and 'Catalonia is Trembling' (11 March 2009), which are highly representative of the 198 episodes broadcast to date. All three add up to 78 minutes of oral language and 12,108 words (3,700 'Catalonia is Trembling', 3,914 'In the Mother's Womb' and 4,494 'The Bullet of Addiction'). We consider that this is a sufficient sample as regards oral language, to provide reliable results. ${ }^{2}$

\subsection{Characteristics of the program}

Each of the Quèquicom programs analyzed deals with a different topic (why earthquakes occur, types of drugs and their effects, problems potentially affecting the fetus during pregnancy, etc.). The selection of topics, in general, by the scriptwriters meets the interests of a family audience and the possibility of them understanding it. Normally they take a certain stance and reinforce it with examples and experts' opinions, but - in some sense - they are ideological. Opposing points of view are not given; rather on the contrary, they defend a perspective on the topic to the end: Drug addicts need professional help and they come out of their addiction; genetic technicians enable very complicated pregnancies to continue successfully, and seismographic experts are very skilled but seismic activity is unpredictable.

The program's hybrid format is based on the segmentation of the topic (although there is a dominant topic, as we have seen, it appears with secondary topics and receives intermittent treatment), the combination of sequences on the set and outside (presenter and reporters talk to affected individuals and experts in one of these two spaces), and the presence of several voices (unlike documentaries, this new format, invites a series of voices which receive a very egalitarian, non-hierarchical treatment), particularly: the presenters (in all the episodes there are two), experts and affected individuals. While the

1 The 17th Television Zapping Award (2011) for the best educational program, granted by Associate Viewers of Catalonia, non-profit consumer association of media, working to quality TV and the rights of users, and grouping more than 17,000 people in Catalonia.

2 Ramón Tomàs, in Payrató (1998: 39) discussing the length of texts, comments: "As long as there are authors who consider reduced samples useless for any research proposal, others believe that if we start to research with a minimum guarantee (cf. Oostdijk 1988 and Biber 1990)... If we focus on each of the texts making up the most important corpora, we will observe that there is a correlation, as regards length, that oscillates between 2,000 and 5,000 words per sample".

Biber (1990) shows, by means of empirical research, that samples of 2,000 and 5,000 words are sufficient representations of the textual categories to which they belong (Biber 1990: 261). 
specialists provide the knowledge, the affected individuals contribute their experience. And the two presenters are the link between all the voices. One of them, on-set, acts as a teacher who explains contents and expands on concepts in an objective and competent manner; the other, off-set in general, plays the role of the alter ego of the audience, asking questions, raising doubts, expressing sensations and feelings, and adding a touch of humor when necessary.

The people on-screen, therefore, and with whom the audience can identify, make up three different groups: Presenters (media professionals who present the program), affected individuals (individuals invited to discuss their relation with the topic; often they are victims) and experts (professionals and academics with experience in the subject that bring an element of objectivity and scientism). Although it may seem that the experts should be the protagonists of these television programs - since the communication of knowledge demands a specialized knowledge controlled by the academic and scientific world -, reality demonstrates that this is not exactly the case: The presenters take the protagonism and are the focal point of the discourse.

\subsection{Analysis and parameters}

The parameters of analysis of our study will be, on the one hand, the ten emotions that are most present in the corpus. As well as compassion, a meta-emotion that generally accompanies the others, 9 more basic emotions must be added, which appear and are combined during the episodes analyzed. The 10 emotions considered in Quèquicom are based on the recognition of two types of valence (positive [pleasure] and negative [displeasure]) and different degrees of arousal, as Russell (1980) suggested in his circumplex model.

Regarding valence, there are 4 positive emotions (admiration, hope, relief and satisfaction), 4 negative (anxiety, dissatisfaction, fear and sadness) and 2 (surprise and compassion) that can be considered with equivocal or mixed valence, using Lazarus terminology (1993). ${ }^{3}$ We noted that two of the emotions (admiration and compassion) do not appear in Russell' repertoire, but we thought appropriate to take them into account: 'admiration' for the expression of feelings mixing pleasure, wonder and approval, and 'compassion' for that meta-emotion or empathic sympathy felt so often by the audience of a media product towards a character, like Zillmann (1991) explains in his Affective Disposition Theory.

Regarding the level of arousal, is high in fear, anxiety, hope, surprise and admiration, medium in compassion, satisfaction and dissatisfaction, and low in sadness and relief.

\footnotetext{
${ }^{3}$ In these programs, surprise is generally a positive emotion, and compassion is a meta-emotion which includes positive and negative valences.
} 
Table 1. Types of emotions

\begin{tabular}{|l|l|l|l|l|l|l|l|l|}
\hline \multicolumn{9}{|c|}{ Compassion (complicity, camaraderie, empathy...) } \\
\hline $\begin{array}{l}\text { Admirati } \\
\text { on }\end{array}$ & Relief & Anxiety & Hope & Dissatisf. & Satisf. & Surprise & Fear & Sadness \\
$\begin{array}{l}\text { Ecstasy } \\
\text { Enthusiasm }\end{array}$ & $\begin{array}{l}\text { Stability } \\
\text { Regret } \\
\text { Resigna- } \\
\text { tion } \\
\text { Tranquili- } \\
\text { ty }\end{array}$ & $\begin{array}{l}\text { Expecta- } \\
\text { tion } \\
\text { Tension } \\
\text { Eagerness } \\
\text { Impatience } \\
\text { Worry } \\
\text { Excitement } \\
\text { Anguish } \\
\text { Hysteria } \\
\text { Remorse } \\
\text { Concern }\end{array}$ & Euphoria & $\begin{array}{l}\text { Disgust } \\
\text { Annoyance } \\
\text { Spite } \\
\text { Anger } \\
\text { Rage } \\
\text { Indignation }\end{array}$ & $\begin{array}{l}\text { Pride } \\
\text { Joy } \\
\text { Tenderness } \\
\text { Gratitude }\end{array}$ & $\begin{array}{l}\text { Fright } \\
\text { Shock } \\
\text { Impact }\end{array}$ & $\begin{array}{l}\text { Fear } \\
\text { Fright } \\
\text { Horror } \\
\text { Panic }\end{array}$ & $\begin{array}{l}\text { Sadness } \\
\text { Pain } \\
\text { Depression } \\
\text { Downhear- } \\
\text { tedness } \\
\text { Let-down } \\
\text { Disappoint } \\
\text {-ment } \\
\text { Solitude }\end{array}$ \\
\hline
\end{tabular}

And on the other hand, the statements that include these in one of the three manners we will describe in point 4.3: Referred, expressed or provoked. Furthermore, these parameters will be created with the classification of the voices proposed in Bassols (2012), in presenters, experts or affected individuals.

The procedure undertaken was the following: Once the episodes had been recorded and viewed, transcriptions were created first, and emotionalizing fragments were located bearing in mind the words, images and the soundtrack.

Secondly, the quantitative weight of each of the emotions was assessed as follows: Speech acts (SA) with emotional content, according to three researchers, have been isolated from the soundtrack; and their duration time has been quantified, using a video with a longitudinal exclusive track for the Time Code Record (TCR), so that the quantitative presence has been assessed in seconds of duration. An example:

PRESENTER 2 (out): Francis and Yolanda are expecting twins. Every week they go to Vall d'Hebron Hospital because they have a high-risk pregnancy. A few days ago they had a bad fright. Their children's lives were in danger.

In this excerpt, the three SA in black are the carriers of emotions and time code indicates that occupy 11 seconds.

Thirdly, the role each emotion plays in the relation established between the participants on-screen, and between them and the viewers, was studied, using the following procedure. There have been several viewings of the film. In the first one we detect emotional speech acts (SA) containing or provoking emotions, and isolate them for the analysis. In the second one we identify which of the 10 emotions are involved in every SA, according to the proposed classification. Thus in the case mentioned above of Presenter 2 would be anxiety and sadness. In the third screening we evaluate the length of each fragment in seconds: 11 in the example. In the fourth one, we determine, following Searle's terminology, if emotions have been referred (assertive SA), expressed (expressive SA) or derived (directive SA, more or less indirect). In the example of the Presenter 2 the speaker does not express any emotion, none is Expressive or Referred, the two are Provoked, facing viewer. In the fifth viewing we try to determine who is the Sender and who the Recipient, and if both are on the screen, or already one has involved the viewer. The Presenter 2 of the example addresses the 
viewer, he is the one who has to experience the Provoked emotion.

Lastly, the emotions were related to the type of voice (presenters, experts and affected individuals) which contribute to the pluri-locutionary nature of the program.

\subsubsection{The 10 emotions of Quèquicom}

If we apply the theories of emotions to a knowledge communication program, such as Quèquicom on TVC, we observe that emotions play a very important role in them. They are programs that require a certain intellectual effort from the recipient and that, therefore, have to establish strategies aimed at attracting and keeping their attention. For this reason, compassion, defined in dictionaries as an empathetic emotion understood as the ability to live the emotions of others, is the pillar supporting the explanation of more or less specialized knowledge, which in our corpus are drug addiction, seismology and neonatology. To achieve this high degree of empathy, the role of the speakers needs to be as important as or more important than the content communicated. Through the emotional identification of the viewers with the participants that appear, the optimum degree of empathy can be obtained, a degree almost as high as that demanded of viewers following dramatic programs or competitions. Beyond this, through emotional narratives, the television media seeks to educate the viewer and encourage them to have positive values and attitudes, of solidarity and courage in the face of adversity, of tolerance towards "different" people, and of respect towards scientific progress (cultivation theory).

In the life stories, the victims' confessions or the experts' examples and explanations (presenters included), the recipient finds diverse emotional gratifications. For example, in the discussion, often positive - negative valence, which emerges at times, refers to a past that has been overcome -, of serious and worrying problems, but which end up being resolved by the scientists; in the presence of suspense - although brief in duration and segmented by the format - which provokes a very controlled anxiety, since it is known that there is a happy ending; in the possibility of overcoming these low or tense moods, seeing how other people confronted with huge problems come out of them; in the pleasure obtained by empathetic emotions established with these people who have had problematic experiences, but who have fought to overcome them; in the eudaimonic satisfaction experienced by obtaining a deeper vision of the human condition and of the meaning of life, and by the awareness of personal growth and self-acceptance; in short, in feeling compensated for having spent their time correctly.

The presenters, from whom we could expect the most objectivity, also have to play with emotionalizing strategies. The nature of the television media itself demands it of them as well as the aspiration to approach the audience in order to earn their loyalty. In this regard, it is interesting to mention the episode on neonatology because, to achieve a high level of compassion, the scriptwriters have made certain to show clearly that the usual presenter (P2) is pregnant. A person who is familiar to the viewers, who enters their house each week via the television screen, is the ideal person to provoke a high degree of emotional identification in the audience.

(1) PRESENTER 2 (her voice discussing the images): Me l'havia imaginat així. Em recorda el seu germà quan va néixer. És la primera imatge del meu segon fill. La 
primera fotografia de la seva cara, però encara a l'interior del meu ventre. Avui és un dia molt especial. M'acompanya el meu marit, el Toni, i ens fa molta il·lusió veure-li la cara. 'I imagined him looking like that. He reminds me of his brother when he was born. It's the first image of my second son. The first photo of his face, but he's still in my womb. Today is a very special day. I'm with my husband, Toni, and we are so happy to see his face'. ("In the Mother's Womb": images from an ultrasound of the fetus and an appointment in a public hospital, background music).

The presenter shows her belly, shows images of her fetus floating in the amniotic fluid and even the affection shared between her and her husband. She is the flesh and bone model on which an artist traces the shape of the placenta and its content. The role of an affected individual is added to that of the presenter, and the emotional effect is doubled. Her story in first person achieves the emotional involvement of all the viewers who have had the same experience, whether as protagonists or as contributors. Who is not amazed by the development of a new life? Who does not identify with the physical and mental effort it requires? The choice of shot amplifies the emotions associated with the presenter's pregnancy (tension and joy). In the following example, she appears in short shots (close-up of her face and belly), which intensify the value of the emotions, and in a tracking shot that includes the pregnant woman, the doctor and the husband, in such a way that it includes all three in the situation. A close-up and detail shot of the ultrasound is also shown, as well as the intertwined hands of the presenter and her husband. There is background music that stops when the specialist speaks.

Of all the emotions, the most present is anxiety, understood as the intense worry about an uncertain or future event, and which can also take on hints of tension, eagerness or anguish.

(2) PRESENTER 2 (off-screen): A Roma ja han trobat cocaïna a l'aire $i$, tot $i$ que no hi ha resultats finals, tot apunta que Roma no es quedarà sola. Hi ha molts indicis que a l'aire de Barcelona també s'hi trobarà cocaïna. 'Traces of cocaine have been found in the air in Rome and, although the final results have not been released, it looks like Rome won't be on its own. It's very likely that there is cocaine in the air in Barcelona too.' ("The Bullet of Addiction": general tracking shot above the city of Barcelona with a zoom, intense electronic music).

(3) PRESENTER 2 (out) Això és la panxa de la Iolanda, embarassada [de bessons] llavors de 17 setmanes $i$ amb problemes molt greus dels seus fetus. 'This is Iolanda's belly. She is 17 weeks pregnant [with twins] and has very serious problems with her fetuses.' ("In the Mother's Womb": ultrasound images, background noise of fetal heartbeat).

Of course, one of the main functions of some voices, especially of the experts and presenters, is to create concern and worry about the facts and the processes explained. Seismology is not explained from an objective point of view, but by referring to the few earthquakes that have occurred in Catalonia and especially to their unpredictable nature, which is qualified as absolute.

(4) PRESENTER 1 (to the camera): És impredictible quan pot haver-hi un terratrèmol. Mireu quina destrossa que ha fet. Aquest terratrèmol no se'l podia esperar ningú. És una cosa inesperada. Per això avui, al Quequicom, parlarem de terratrèmols. 'It is impossible to predict when there will be an earthquake. Look at 
the destruction it causes. No-one could have expected this earthquake. It is unexpected. That is why today, on Quequicom, we will discuss earthquakes.' ("Catalonia is Trembling": medium shot of the presenter and background music).

Drug addiction is becoming a plague, as a result of the toxic residues found in rivers, coming from an apparent "mass" consumption.

(5) PRESENTER 2 (close-up): Imaginin quanta gent ha de consumir drogues perquè n'arribin al riu. Per treure'n l'aigua clara ens emportem les mostres al laboratori. 'Imagine the number of people who must take drugs in order for them to reach the river. To extract clear water we will take the samples to the laboratory.' ('The Bullet of Addiction": expert and presenter in a river, background noise).

The pregnancies followed in the neonatology episode are complicated and up to a certain moment uncertain.

(6) PRESENTER 2 (out): La Iolanda i el Francesc esperen bessones. Cada setmana van a la Vall d'Hebron perquè tenen un embaràs d'alt risc. Fa dies van tenir un gran ensurt. La vida de les seves filles estava en perill. 'Iolanda and Francesc are expecting twins. Every week they go to Vall d'Hebron hospital because they have a high-risk pregnancy. A few days ago they had a bad fright. Their children's lives were in danger.' "In the Mother's Womb": the parents in a car and a shot of the waiting room in the hospital, traffic noise and the background hum of the hospital).

Anxiety, as an anticipatory effect of dramatic programs, acts as bait for the recipient's attention. The viewer instinctively seeks a favorable outcome for their worry, an outcome that comes in the form of a happy ending: The drug addict goes into rehabilitation and wants to be an artist, the premature babies survive and earthquakes are greatly neutralized thanks to stricter laws regarding the construction of housing. The excitement provoked by the uncertainty and tension of certain moments intensifies the joy following the happy ending, especially if it involves a participant towards whom the viewer has a positive feeling.

The second emotion present is sadness, in other words, the moral pain that emerges from compassion or that can coexist with fear. It takes this second position, especially in the episodes in which the role of the affected individuals is fundamental, such as in the episode dedicated to drug addiction, which shows the narrative testimony of the addiction and recovery processes of a young man, and of his mother's suffering. If it stems from compassion, we can say that it is also an empathetic emotion, which emerges when the recipient lives the conflicts "of others" intensely, but is deeply affected by them due to the moral judgment they have made of them.

(7) PRESENTER 2 (off-screen): Per la Mari Carmen ha estat molt dolorós saber tot el que va fer el seu fill d'amagat durant els anys de consum. 'It was very painful for Mari Carmen to find out what her son did behind her back during his consuming years.' ("The Bullet of Addiction": cooker with a saucepan on the ring, American shot of the mother's hands, background silence).

The program enters her house. She shows us the kitchen and the bedroom where they sleep, in an attempt to set the scene for the dramatic action; the setting of the media context, as we have previously mentioned. We can imagine what happens between these 
four walls. We see people suffering, sad and in conflict, and we also feel sad for their suffering. The mother of the drug addict appears almost always in American shot and in the space of the kitchen, where she welcomes the rest of the family. The detail shots (of hands, in this example), the pauses in speech, the close-up showing the mother wiping her tears with her apron and the absence of music intensify this emotion.

Almost as important, in third position, we find relief and satisfaction, two positive emotions. However, while the former follows pain, anxiety or fear, the latter corresponds to the fulfillment of a desire or a need. When we experience them in accordance with the media characters, they are also empathetic emotions. Perhaps, in this regard, the most interesting episode is that dedicated to neonatology, because the mothers and fathers provide us with very intense moments stemming from these two emotions. They fear that the pregnancies will not continue or that they will be problematic and, therefore, show huge relief when everything turns out well.

In many cases there is a progression of tension-relaxation-tension-relaxation. For example, presenter 2 from "In the Mother's Womb" constructs a discourse that expresses and provokes a certain degree of anxiety and expectation.

(8) PRESENTER 2 (out): Si l'operació ha anat bé aquesta visita és crucial. L'exploració és llarga i exhaustiva. A través de l'ecografia, la doctora Carreras veu si les bessones s'han recuperat. 'If the operation has gone well, this appointment is crucial. The examination is long and tiring. Via the ultrasound, Doctor Carreras sees if the twins have recovered.' ("In the Mother's Womb": close-up of the mother lying on the bed in the doctor's room and tracking shot with the doctor; intense music).

However, after this brief moment of anxiety, relief is brought by the expert, the doctor looking after the pregnant woman.

(9) EXPERT 2 (to the parents): L'important és que segueixin el seu propi ritme i això sí que sembla que ho estan fent bé, eh? Bueno, doncs, paciència i anar fent, eh? 'What is important is that they follow their own rhythm and it seems that they are doing that well. So, patience and keep going as you are, ok?'

And the resulting satisfaction and complicity of the father:

(10) AFFECTED INDIVIDUAL 2: Moltes gràcies. És molt important. Quan s'ha fet l'operació s'ha fet bé $i$ això és tècnicament lo que importa, no? I ara és qüestió de la naturalesa. Les sensacions són bones, no?. Eh, Iolanda? 'Thank you very much. It's very important. When the operation was done it was done correctly, and that's what matters, isn't it? Now it's up to nature. But we have a good feeling, don't we Iolanda?'

Corroborated by the mother with a "yes".

In this scene, the combination shots emphasize the role of support between the doctor and the affected individuals, and the close-ups of the mother lying on the bed intensify the emotions of tension and relief. The music becomes more intense when the presenter seeks to generate expectation, and disappears completely, as usually occurs on this program, during the dialogue between the doctor and the couple.

The young man's exit from drug addiction is also portrayed in a similar way. The 
tension maintained during the program is different however, in the two cases. In the case of the drug addict, rather than fear it is dissatisfaction that leads him to consume increasingly and to seek relief.

(11) AFFECTED INDIVIDUAL 1: Després comences a baixar $i$ comences a baixar molt fort, molt en picat, $i$ és lo que fa la primera muntanya de la serra, diguéssim, però després tornes a pujar, però ja no arribes fins a dalt de tot on havies arribat abans. Cada vegada vas pujant $i$ baixant, pujant $i$ baixant, $i$ cada vegada estàs més a baix, més al fons. I arriba un moment que ja veus el fons, l'estàs tocant. 'Then you start to come down and it happens very quickly. That's what the first mountain is like. You get high, but you don't get as high as you used to. Each time you get high and come down, get high and come down, and each time you come down lower. And the time comes when you've hit rock bottom, you're touching it.' ("The Bullet of Addiction": close-up of the man, background silence).

However, in this case, we know from the start that the man comes off drugs because the camera shows him peacefully walking his dog. The conflict is in the past, something that has already been overcome when the episode starts. On the contrary, in the case of the pregnant mothers, the intrigue, based on fear rather than dissatisfaction, is maintained for longer. The relief does not come until the end. It is an example of "suspense", a highly appreciated cinematographic resource.

(12) AFFECTED INDIVIDUAL 1: Hem passat molta tensió fins arribar aquí, eh? I llavòrens, clar, que et diguin que et facis l'operació $i$ que et diguin "tècnicament estem molt contents": Això que t'ho digui un equip mèdic, quan els metges sempre són molt prudents, clar, és que t'omples d'esperança, no? I realment és una injecció de moral molt forta. 'We've been through some tense times before getting to this point. So, of course, when they tell you to have the operation and then they tell you that "technically we are very happy"; that a medical team tells you that, when usually doctors are very cautious, well, of course, you get your hopes up. It really boosts your morale.' ("In the Mother's Womb": outside the hospital, close-up of the parents, intense music).

As regards hope, it appears on occasions in all the episodes but it has great anticipatory strength because it often corresponds to the anticipation that, in the future, something very desired by the participants will happen and, therefore, the recipient empathetically wants this event to happen. Hope shows us the more positive side and focuses on the future, on the progress of facts. In this regard, the ex-drug addict says:

(13) AFFECTED INDIVIDUAL 1 (out): Vull ser dibuixant de còmics, o això ha estat sempre el meu somni, no? Fer una novel-la gràfica, està allà. 'I want to be a comic artist. That has always been my dream. To write a graphic novel. It's there.' ("The Bullet of Addiction": detail shot of the man's drawing, background music).

The dissatisfaction and isolation that led him to consume have been overcome, and the person is looking to the future and seeing it in a positive light. He transmits the message that he wants to live and to do make the most of his life. He explains how hopeful he is. The setting, the camera and the sound complete the identity of this affected individual, who appears in spaces with positive connotations (walking his dog on the street; in his house, drawing; in the kitchen, with his parents). He is shown in 
close-ups and detail shots, especially his hands while he is drawing. The music is soft, except when he is talking about his past as a drug addict, when there is intense, electronic music.

The pregnant women in "In the Mother's Womb" are full of hope. Perhaps the most explicit is that of the presenter herself.

(14) PRESENTER 2: Ens fa molta il.lusió veure-li la cara [al nadó]. 'We can't wait to see his face [the baby's].' ("In the Mother's Womb": tracking shot from the presenter's feet to her belly. She is lying on a bed in the doctor's room. Background music.)

As regards admiration, it is a less common emotion than the other emotions mentioned, but it is often applied to babies and animals. In our corpus it can be found in the spellbound look of the parents when they see their babies in the ultrasound or when they have just been born.

(15) PRESENTER 2, AFFECTED INDIVIDUALS 1 AND 2 (at the same time): Ara ara, mira! 'Now, now, look!' ("In the Mother's Womb": ultrasound image of the fetus moving. It looks like he is smiling when he hears the music played through earphones on the mother's belly).

Or when they enjoy holding their premature baby in their arms.

(16) AFFECTED INDIVIDUAL 3: Es una campeona, eh? Es una campeona, mi niña, A que sí? 'She's a champion, isn't she? My little girl's a champion.' ("In the Mother's Womb: close-up of the girl, intense music).

Of course, the emotional images play a more important role than the words of the expert to the viewer processes and memorizes the scientific message: The ability of a fetus to "enjoy" music or of a premature baby to recognize its mother's voice.

Surprise deserves a separate mention. It corresponds to the need to provide new knowledge or new aspects of knowledge in order to keep the audience's attention and satisfy their eudaimonic expectations. The viewer of this type of programs is driven by their self-development, and wants the knowledge to change them and their everyday life.

Thus, it seems that it is also a meta-emotion, like compassion, which has already been discussed; because the interest of any program is based on contributing new knowledge, that can surprise the viewer and with which they feel satisfied. It is found in more or less isolated fragments, which may be more intense. In the episode on drug addiction, the media seeks to find and focus on unexpected aspects, which help to capture the viewers' attention: Surprise comes especially from the fact that drug consumption is higher than what people think; and from the statement by an expert that we are all susceptible to becoming hooked to an addictive substance.

(17) EXPERT 2: Pero, claro, a la fecha actual, desconocemos totalmente quien es el que es el vulnerable... Entonces, pues consumir una droga es jugar a la ruleta rusa, no sabemos si nos va a tocar la bala de la adicción o si no nos va a tocar. 'But, of course, today, we do not know who is vulnerable...So, consuming a drug is like playing Russian roulette; we don't know if the bullet of addiction is going to be for us or not.' ("The Bullet of Addiction": close-up of the pharmacist in the laboratory, 
background noise).

On the contrary, in the episode on neonatology surprise stems from the abilities of the fetuses and newborns.

(18) PRESENTER 2: És realment impressionant $i$ sobretot veure que realment es mou molt més del que jo noto. 'It really is incredible, and especially to see that he moves a lot more than I notice.' ("In the Mother's Womb": close-up of ultrasound, background music).

In the episode on seismology, the surprising aspect is that there has been so little architectural precaution (which requires extremely simple solutions), considering the constant seismic activity of the territory in which the viewers live.

(19) PRESENTER 2: Això és així de simple? O sigui, un arquitecte, a l'hora de voler fer un edifici, per fer-lo resistent als sismes, n'hi ha prou a tenir coses així tan simples en compte $i$ ja està? 'It's that easy? So, when an architect wants to design a building, to make it earthquake resistant, they only have to take those few simple things into consideration? That's it?' ("Catalonia is Trembling": medium shot of the presenter speaking to the expert, background noise).

\section{Results}

\subsection{Emotions}

In order to be able to assess the specific weight of each of the emotions, we deemed it relevant to consider the amount of time the scriptwriters dedicate to them, the amount of time during which they are activated through the verbal code, through direct references or direct expressions by the participants on screen. At times, the emotions are part of the script, at times spontaneous statements, but they are always selected by the scriptwriters and therefore, they are part of the program's communication strategies.

The results obtained from the quantification of the length of the discursive fragments in which they are activated are the following:

Table 2. Presence of emotions in the three episodes, in seconds and percentages ${ }^{4}$

\begin{tabular}{|c|c|c|c|c|c|c|c|c|c|}
\hline & Admiration & Relief & Anxiety & Hope & Dissatisf & Satisf. & Surprise & Fear & Sadness \\
\hline \multirow{3}{*}{$\begin{array}{l}\text { Catalonia } \\
\text { is } \\
\text { Trembling }\end{array}$} & 0 seconds & $12 \mathrm{sec}$. & $146 \mathrm{sec}$. & $4 \mathrm{sec}$. & 0 & 0 & $24 \mathrm{sec}$. & $7 \mathrm{sec}$. & $6 \mathrm{sec}$. \\
\hline & & & & & & & & & \\
\hline & & $6.10 \%$ & $73.00 \%$ & $2.00 \%$ & & & $12.20 \%$ & $3.30 \%$ & $3.10 \%$ \\
\hline \multirow{3}{*}{$\begin{array}{l}\text { In the } \\
\text { Mother's } \\
\text { Womb } \\
\end{array}$} & $18 \mathrm{sec}$. & $86 \mathrm{sec}$. & $151 \mathrm{sec}$. & $18 \mathrm{sec}$. & 0 & $84 \mathrm{sec}$ & $59 \mathrm{sec}$. & $2 \mathrm{sec}$. & $32 \mathrm{sec}$. \\
\hline & & & & & & & & & \\
\hline & $4.00 \%$ & $19.10 \%$ & $33.55 \%$ & $4.00 \%$ & & $18.60 \%$ & $13.10 \%$ & $0.44 \%$ & $7.10 \%$ \\
\hline
\end{tabular}

\footnotetext{
${ }^{4}$ The negative valence emotions are in the grey columns and the positive valence emotions are in the white columns.
} 


\begin{tabular}{|l|l|l|l|l|l|l|l|l|l|}
\hline $\begin{array}{l}\text { The Bullet } \\
\text { of } \\
\text { Addiction }\end{array}$ & 0 seconds & 27 sec. & $241 \mathrm{sec}$. & $23 \mathrm{sec}$. & $74 \mathrm{sec}$. & $72 \mathrm{sec}$ & $18 \mathrm{sec}$. & $22 \mathrm{sec}$. & $197 \mathrm{sec}$. \\
\hline \hline & & & & & & & & \\
\hline \hline & & & & & & & & & \\
\hline \hline
\end{tabular}

Anxiety is the predominant emotion in the three episodes, to such an extent that it is dedicated a minimum of one third of the time. Therefore, it is clear that it is the most important resource when endeavoring to obtain the emotional participation of the recipient. In addition, the tension involved intensifies the enjoyment of a happy ending. In the case of "Catalonia is Trembling", since it is a topic that affects the viewer - the news often contains items on devastating earthquakes in other countries and on mild but worrying earthquakes in the territory -, the percentage increases considerably, to more than double. The more spectacular the controversial topic (in terms of its rarity and originality, such as an earthquake in Catalonia), the higher the possibilities of emotionally involving the audience. Perhaps for this reason sadness is the second most important emotion, especially on account of its presence in the episode on drug addiction, in which both the affected individual and the parents display it considerably. Therefore, two axiological negative emotions are at the top of the classification, and will be balanced out, more or less, with others of equal or different polarities. Interestingly, anxiety and sadness are two of the four basic emotions. On the contrary, the other two, anger and joy, are not present. The former does not appear at all; possibly because the media does not accept it. The latter may appear to be too superficial for a program of scientific content.

Relief and surprise are in an intermediary position; relief because it eases the tension caused by anxiety and surprise because it keeps the viewers' attention.

The least common emotions are admiration, hope, fear and dissatisfaction. As regards admiration, only one presenter on "In the Mother's Womb" admires the behavior of an affected individual. But it is not at all a usual reaction on the program. In the case of hope, the emotion appears to be associated with the character of a witness and appears depending on the invited person and not within the presenters' discourse. This is similar to what occurs with fear. As regards dissatisfaction, it is clear that dissatisfied witnesses are not given a chance to speak, since it is not a complaint program. This is not the aim of this type of program. It could be but it is not the case. When dissatisfaction appears, as in the episode on addiction, it is to show that it has been overcome, that balance has been re-established. It is surprising to see, on the contrary, the greater presence of its antonym, satisfaction, which two of the episodes, "In the Mother's Womb" and "The Bullet of Addiction" use.

Looking at each of the episodes, it can be stated that the topic examined conditions the presence of one emotion or another. More specifically, the episode aimed at explaining seismic activity in Catalonia plays with surprise based on the usual frequency of earthquakes, however small they may be, and relief stemming from the fact that everything is monitored. The episode about the risk pregnancies does so with satisfaction and relief felt by the affected individuals once processes which always, in the program, turn out well have come to an end. In the program dedicated to drug addiction the emotional game is based on the sadness of the affected individuals (drug addict and relatives) but also on the relief of a happy ending. In short, the "cultivation" is positive: The affected individuals come out of the situation, social solidarity is 
established, the techniques work... The "human" topics that are treated positively tend to calm the viewers' mood, and in addition, give them the "peace" to spend their time "well" with educational programs: It may be a choice that manages their mood.

\subsection{Voices}

Of all the speakers present on the program, whether presenters, affected individuals or experts, those who channel emotions most in the programs analyzed are Presenter 2 who accompanies and complements Presenter 1-, the affected individuals - who are invited on account of their emotional relation with the topic - and the experts, in this order of importance. Only P1 cannot allow himself to channel emotions because his role as a teacher demands a more serious and more distant stance.

Table 3. Voices that use emotions more in seconds:

\begin{tabular}{|c|c|c|c|c|}
\hline & Total time & \multirow{2}{*}{$\begin{array}{l}\text { Affected } \\
\text { individuals }\end{array}$} & \multirow[t]{2}{*}{ Presenters } & \multirow[t]{2}{*}{ Experts } \\
\hline & & & & \\
\hline \multirow{2}{*}{$\begin{array}{l}\text { Catalonia is } \\
\text { Trembling }\end{array}$} & $199 \mathrm{sec}$. & & \multirow{2}{*}{$\begin{array}{l}134 \mathrm{sec} . \\
67.3 \%\end{array}$} & \multirow{2}{*}{$\begin{array}{l}62 \mathrm{sec} . \\
31.15 \% \\
\end{array}$} \\
\hline & & & & \\
\hline \multirow{3}{*}{$\begin{array}{l}\text { In the } \\
\text { Mother's } \\
\text { Womb }\end{array}$} & $374 \mathrm{sec}$. & \multirow{3}{*}{$\begin{array}{l}83 \text { sec. } \\
23.8 \%\end{array}$} & \multirow{3}{*}{$\begin{array}{l}234 \mathrm{sec} . \\
61 \%\end{array}$} & \multirow{3}{*}{$\begin{array}{l}57 \mathrm{sec} . \\
14.2 \%\end{array}$} \\
\hline & & & & \\
\hline & & & & \\
\hline \multirow{2}{*}{$\begin{array}{l}\text { The Bullet of } \\
\text { Addiction }\end{array}$} & $674 \mathrm{sec}$. & \multirow{2}{*}{$\begin{array}{l}476 \mathrm{sec} . \\
70.6 \% \\
\end{array}$} & \multirow{2}{*}{$\begin{array}{l}101 \mathrm{sec} . \\
14.98 \%\end{array}$} & \multirow{2}{*}{$\begin{array}{l}78 \mathrm{sec} . \\
11.57 \%\end{array}$} \\
\hline & & & & \\
\hline
\end{tabular}

\section{Presenter 2 (reporter)}

They appear to be eager to learn, and to satisfy this eagerness, approach specialists and affected individuals, who provide them with the necessary information. This way of acting turns them into a kind of alter ego of the viewer, asking questions, becoming surprised, becoming excited and investigating on their behalf. They are extremely empathetic towards the affected individuals and the audience. They link diverse information and lead the viewer from one speaker to another. They are the main carrier of the emotions referred to and experienced in these programs. When there are no affected individuals, such as in "Catalonia is Trembling", we might say, so to speak, that they are the Big Emotions Such as in this case of surprise:

(20) PRESENTER 2: És fortíssim, no? O sigui, he notat realment com el terra es movia. 'It's incredible, isn't it? I mean, I really noticed how the earth moves.' ("Catalonia is Trembling": speaking to the camera, siren in the background).

Presenter 1 only has a small presence in the emotionalizing fragments in "In the Mother's Womb", perhaps due to his proximity to Presenter 2 who is also the affected individual. 


\section{Affected individuals}

They make up the second column of the programs. They are invited to participate due to their personal experience of an event, whether they experienced it personally, or as a direct witness. Their contribution consists of explaining the experience, in such a way that they are a privileged source of emotional expression in the programs. The complexity and gravity of the experiences revealed move the viewer, who can empathize:

(21) AFFECTED INDIVIDUAL 2: Cuando te dice tu hijo que tiene problemas con la cocaína es que te se rompe el corazón. No es que te duela y que te sientas, es que te se rompe el corazón. 'When they tell you your son has a cocaine problem it breaks your heart. It's not that it hurts and you're sorry, it breaks your heart.' ("The Bullet of Addiction": medium shot of mother, background kitchen noise).

\section{Experts}

The expression of emotions through the discourse of the experts helps to show that the contents they explain are important to the viewer, that they have a link with their life, and that they are not unrelated. It is a resource that contributes towards getting closer to the audience. It is worth noting, however, that the emotions of the experts only emerge when they are not directly transmitting the scientific knowledge and when they adopt the role of an ordinary person. Then, the expert shows a certain frustration; a certain sadness.

(22) EXPERT 2: Todo el mundo tiene una mayor o menor vulnerabilidad para padecer un fenómeno adictivo. El problema es que esta vulnerabilidad no la conocemos. Si la conociéramos sería muy fàcil. 'Everyone has a higher or lower vulnerability to suffer from an addictive phenomenon. The problem is that we do not know what this vulnerability is. If we knew, it would be very easy.' ("The Bullet of Addiction": close-up of the expert in his laboratory, background noise).

\subsection{Mode}

While images, sound and music evoke emotions in the recipient, in verbal discourse we have three possible measures of stimulating the emotional world: Reference, expression and provocation. This is very much in line with the well-known classification of speech acts by Searle (1969), of which the representative, expressive and directive, related with emotions, would be the most habitual in our corpus.

Referred emotions are those that are part of a representative speech act, meaning one that discusses reality. In this case, for example, part of the reality that is an emotion, in particular fear.

(23) EXPERT 3: La gent es va esverar per la remor i per la pols i per tota la història. 'People got flustered with the noise and the dust and the whole event.' "'Catalonia is Trembling": inside a gothic church, religious music). 
Expressed emotions are those that form part of an expressive speech act, meaning one that reveals an emotion experienced by the speaker. The young ex-drug addict clearly expresses his joy.

(24) AFFECTED INDIVIDUAL 1 (off-screen): Les ganes de consumir encara hi són, $i$ sé que hi seran sempre. Però, bueno, lluitant sempre amb les eines que $m$ 'heu donat aquí [al centre de rehabilitació] $i$ estic content. 'The desire to consume is still there, and I know that it always will be. But, I'm fighting with the tools they have given me here [in the rehabilitation center] and I'm happy.'

If we take a quick glance at the emotionalizing fragments and divide them into referred or expressed emotions, we observe that more than one third (36.1\%) correspond to emotions expressed by the speakers and almost one quarter $(22.4 \%)$ to referred emotions. However, what is even more interesting is that the rest, almost half, are emotions that are both referred and expressed. This means that while the speakers speak of an emotion, they also experience it.

(25) PRESENTER 2: Feien [els fetus] només 15 centímetres, o sigui, que m'hi cabien aquí, als palmells de les mans. I pesaven només 200 grams. 'They [the fetuses] only measured 15 centimeters. I mean, they'd fit here, in the palm of my hands. And they only weighed 200 grams.' ("In the Mother's Womb": P2 shows P1 a book of photographs of fetuses, background music).

The presenter explains the feeling of sadness she had when she saw the tiny fetuses being operated on. However, it is clear that she also relives and reproduces the sensation of that moment again when she explains it.

If this typology of emotions (referred and expressed) is related with the voices, it can be observed that Presenter 2 of "In the Mother's Womb", a maximum emotionalizing model because she is also an affected individual, refers to emotions and expresses emotions during the entire program. And Presenter 2 of "Catalonia is Trembling" expresses emotions when the focus is on him and he refers to them when he speaks off-screen. As regards the affected individuals, normally while they explain what they felt they relive their emotions in front of the camera.

Provoked emotions, on the contrary, are those that form part of the illocutionary strength of a speech act. In other words, they are the emotions the speaker wants to provoke in the recipient (whether he achieves it or not is another matter). In the corpus, emotions are referred to on the basis of the morphosyntactic and lexical choices of the speakers of the program; or of the images, the sound and the music included in it.

(26) AFFECTED INDIVIDUAL 1: Em trobava molt a dalt... veia que em relacionava amb la gent. La gent era ... clar, la festa, la nit. Tots som molt amics, tots ens coneixem, tots molt col-legues.. Això... veia que triomfava. 'I was at the top...I saw that I related to people. People were... of course, partying, night time. We are all great friends, we all know each other, we're all mates...So...I thought that I was winning.' ("The Bullet of Addiction": the man walking in a green area with his small dog, soft background music).

While the affected individual expresses the satisfaction he felt when he was taking heroin, his narration has surely been chosen to generate sadness in the viewer. One of the emotions, satisfaction, is referred; and the other, sadness, is provoked. These 
are multi-level emotions.

The provoked emotions are more general, more common. It can be said that each segment is selected to provoke, in general, one or two emotions. All the fragments in one episode can even provoke the same emotion. So, for example, "Catalonia is Trembling" seeks to provoke surprise and anxiety all the time. On the contrary, "In the Mother's Womb" looks for a high degree of compassion/empathy, in general; but in some fragments it endeavors to provoke satisfaction (tenderness), in others relief, and in some surprise (towards new knowledge). "The Bullet of Addiction", in turn, plays with sadness in the first part and with hope in the second ${ }^{5}$.

\section{Conclusions}

From the analysis of the episodes of the program examined, a number of conclusions emerge which we think can be extrapolated to the television program in general, considering the size of the corpus.

The program Quèquicom achieves, like communication programs in general, the objective of self-satisfaction of the audience, due to the fact that it contributes towards their intellectual development. Its "cultural" nature, recognized by the social group, backs this up. Moreover, through the presentation of problematic cases that end up working out positively thanks to the efforts of many people, it seeks to influence the values and attitudes of the audience, in an attempt to achieve a more supportive society that is more prepared to overcome adversities. However, it also has to fulfill the desire for emotional satisfaction of its target audience, which wants to learn but also be entertained. To do so it uses strategies such as dramatization and emotionalization.

Narrativization has increased in this new format, if we compare it with traditional documentaries. The testimonial speakers on documentaries, who had a specific weight that was much lower than that of the experts and the explicative offscreen voice, have been superseded by those of the affected individuals on Quèquicom, in such a way that their experience has been selected more than the expertise of specialists, and life stories occupy more space than referential explanations.

To achieve this narrativization, the program shows conflict resolution processes that are invariably accompanied by a notable emotional presence aimed at emotionally involving the viewer. In this game, anxiety and compassion always lead to overcoming the negative effects of actions, with the resulting relief and pleasure in the audience. Emotions are used as a means of establishing specialized contents; they help to understand and measure the topic being studied, with life stories that illustrate the experts' explanations, but they also help to increase the plausibility of these conflictive stories.

The entertainment element mentioned, in turn, promotes the fact that the emotions chosen never reach a maximum excitement value and always end with a final state of emotional satisfaction. As regards the valence, this element means that it is mainly positive, referred to especially in the actions of the affected individuals (often led by hope), rather than in the places or things mentioned. However, it is also negative in the expressions of emotions shown, for example sadness or fear. Often they receive a

\footnotetext{
${ }^{5}$ Evidently, this work is not a study on reception but we were obliged to carry out a small sample with viewers of different ages in order to see if the referred appreciations coincided with the derived emotions.
} 
hyperbolic treatment. Some are aimed, however, at encouraging a feeling of control over the life of the viewers, through the relief from the anxiety provoked in them. The emotional disposition that is expected of the viewer is positive towards the affected individuals (mothers, premature babies and doctors, or the ex-drug addict Jonathan), who are seen as good people, heroes, who they want to see triumph.

The television avails of many resources to achieve the objectives of educating and entertaining on account of its multi-modal nature. Thus, as well as verbal discourses, image and sound intensify emotions and help to create an emotional setting of positive or negative valence. The selection of shots and sounds when the program is edited is key to defining the emotionalizing fragments and indicating the nature.

As regards the typology of the emotions used, empathetic emotions have a notable role; in other words, those which contribute towards bringing the protagonists and the viewers closer, to their identification. Moreover, there are many multi-level emotions, derived from the fact that compassion acts in conjunction with many others. Lastly, it is important to mention those emotions that provoke "psychological wellbeing", often at the end, that the audience needs for their emotional satisfaction.

The meta-emotion "compassion" superimposes all the emotions found in the majority of cases and may contribute remarkably to empathy in the recipient and to the fact that they experience eudaimonic gratifications. Often, compassion drifts towards sadness, anxiety and relief, following the vicissitudes and achievements of the participant with whom the recipient establishes a positive emotional filiation. When the program does not include life stories, the basic emotions "anxiety" and "surprise" increase the interest in the topic explained because the former contributes towards creating the suspense required to keep the audience hooked to the plot and wanting to know how it will end, and the latter satisfies their desire for personal growth, due to the new knowledge provided by the program.

Other than compassion, the five positive emotions found can be listed, from greater to lesser presence, as satisfaction, relief, surprise, hope and admiration. The four negative emotions can be listed as anxiety, sadness, dissatisfaction and fear.

As regards the speakers who provoke emotions, Presenter 2, who has a notable role in this regard, acts like an alter ego of the viewer. He is portrayed as a silly clown compared to Presenter 1 who comes across as an expert, a wise man. The affected individuals however, also play an important role as emotional provokers through their accounts of their life stories.

Lastly, regarding the nature of emotions according to the classification we proposed of referred, expressed and provoked emotions, the high presence of emotions that are both referred and expressed, almost half, reveals that the media does not only want affected individuals to explain the emotions they felt but it wants them to relive it, to suffer again in front of the viewer. Only in this way can a maximum threshold of emotional provocation and empathy be achieved.

It is very clear that the media in general, and scriptwriters in particular, work with the emotions present in the voices of those participants who interact in the program. They select the most intense, most emotional moments. And they seek narrations and explanations that refer to them, but also a live public exhibition of the emotions felt with the intention of generating them again in the viewers. It is an attempt at establishing a game of shared and recognizable emotions. In fact, this is one of the oldest rhetorical resources at the service of a targeting and amplifying medium such as television, even though the content of the program is scientific. 


\section{References}

Aristotle (1995) Poétique. Paris: Les Belles Arts.

Barlett, Ch.P., and D.A. Gentile (2011) Affective and emotional consequences of the mass media. In K. Döveling, Ch. von Scheve, Christian and E.A. Konijn (eds.), The Routledge Handbook of Emotions and Mass Media. London and New York: Routledge, pp. 60-78.

Bassols, Margarida (coord.) (2012) La divulgació en els nous formats televisius. Bellaterra: Publicacions de la Universitat Autònoma de Barcelona.

Berger, Seymour M. (1962) Conditioning through vicarious instigation. Psychological Review 69: 450466.

Boyd-Barrett, O., and P. Braham (eds.) (1987) Media, Knowledge and Power. London: Croom.

Bryant, J., and D. Zillmann (1994) Media Effects. Advances in Theory and Research. Hillsdale, New Jersey: Lawrence Erlbaum.

Calsamiglia, H., and C. López Ferrero (2003) Role and position of scientific voices: Reported speech in the media. Discourse Studies 5.2: 147-73.

Calsamiglia, H., and T. Van Dijk (2004) Popularization discourse and knowledge about the genome. Discourse and Society 15.4: 369-89.

Carmona, Ramón (1996) Cómo se comenta un texto fílmico. Madrid: Cátedra.

Casetti, F., and F. de Chio (1991) Cómo analizar un film. Barcelona: Paidós.

Charaudeau, Patrick (2008) La médiatisation de la science. Clonage, OGM, manipulations genètiques. Bruxelles: De Boeck.

Chaume, Frederic (2004) Cine i traducción. Madrid: Cátedra.

Condry, John (1989) The Psychology of Television. Hillsdale. NJ: Lawrence Erlbaum.

Cosmides, L., and J. Tooby (2000) Evolutionary psychology and the emotions. In M. Lewis, and J.M. Haviland-Jones (eds.), Handbook of Emotions. New York, NY: Guilford, pp. 91-115.

Cros, A., M. Bassols, G. Brunat, and C. Gónzalez (2102) Television and the mediatization of knowledge: Discursive strategies in new TV formats. Catalan Journal of Communication and Cultural Studies, Volume 4 Number 1.

De Semir, Vladimir (2011) Metaanálisis: comunicación científica y periodismo científico. La crisis de los medios de comunicación. Madrid: Fundación Española de la Ciencia y la Tecnología.

Detenber, B.H., and A. Lang (2011) The influence of form and presentation attributes. In K. Döveling, Ch. von Scheve, and E.A. Konijn (eds.), The Routledge Handbook of Emotions and Mass Media. London and New York: Routledge, pp. 275-293.

Döveling, K., Ch. von Scheve, and E.A. Konijn (eds.) (2011) The Routledge Handbook of Emotions and Mass Media. London and New York: Routledge.

Ewoldsen, D.R., J.H. Yu, and N. Rhodes (2004) Fear appeal messages effect accessibility of attitudes toward the threat and adaptive behaviors. Communication Monographs 71: 49-69.

Fredrickson, Barbara L. (1998) What good are positive emotions? Review of General Psychology 2.3: 300-19. 
Friestad, M., and E. Thorson (1986) Emotion - eliciting advertising - effects on long-term-memory and judgment. Advances in Consumer Research 13: 111-16.

Frijda, Nico H. (1988) The laws of emotion. In J. Jenkins, K. Oatley, and N. Stein (eds.), (1998) Human Emotions: A Reader. Malden: M.A. Blackwell Publishers, pp. 271-287.

Galati, D., B. Sini, S. Estaún Ferrer, O. Soler Vilageliu, and P.M. Mateos García (1998) The emotion lexicon in Neo-latin languages. In A.H. Fisher (ed.), ISRE'98 Proceedings of the Xth Conference of the International Society for Research on Emotion. Wursburg I.S.R.E. Edition, pp. 214-218.

Gerbner, George (1998) Cultivation analysis: An overview. Mass Communication and Society 3/4: 175194.

Gerbner, G., L. Gross, M. Morgan, and N. Signorielli (1986) Living with television: The dynamics of the cultivation process. In J. Bryant, and D. Zillman (eds.), Perspectives on media effects. Hilldale, NJ: Lawrence Erlbaum Associates, pp. 17-48.

Gerbner, G., L. Gross, M. Morgan, and N. Signorielli (1994) Growing up with television: The cultivation perspective. In J. Bryant, and D. Zillmann (eds.), Media Effects. Advances in Theory and Research. Hillsdale, New Jersey: Lawrence Erlbaum, pp. 17-41.

Hamilton, V., G.H. Bower, and N.H. Frijda (eds.) Cognitive perspectives on emotion and motivation. Dordrecht: Kluwer.

Kleinginna, P.R., and A.M. Kleinginna (1981) A categorized list of emotion definitions, with suggestions for a consensual definition. Motivation and Emotion 5.4: 345-379.

Konijn, E.A., and J.M. ten Holt (2011) «From noise to nucleus». Emotion as key construct in processing media messages. In K. Döveling, Ch. Von Scheve, and E.A. Konijn (eds.), The Routledge Handbook of Emotions and Mass Media. London and New York: Routledge, pp. 37-59.

Lang, A., P. Bolls, R.F. Potter, and K. Kawahara (1999) The effects of production pacing and arousing content on the information processing of television messages. Journal of Broadcasting and Electronic Media/ Fall, pp. 451-475.

Lang, A., and D.R. Ewoldsen (2011) The measurement of positive and negative affect in media research. In K. Döveling, Ch. von Scheve, and E.A. Konijn (eds.), The Routledge Handbook of Emotions and Mass Media. London and New York: Routledge, pp. 79-98.

Lazarus, Richard S. (1993) from psychological stress to the emotions: A History of changing outlooks. Annual Review of Psychology 44: 1-21.

Lazarus, Richard S. (1966) Psychological Stress and the coping process. New York: McGraw-Hill.

Lewis, M., and J.M. Haviland-Jones (eds.) Handbook of Emotions, 2nd edn. New York City, NY: Guilford.

Miceli, M., and C. Castelfranchi (2003) Crying: Discussing its basic reasons and uses. New Ideas in Psychology 21: 247-73.

Moirand, Sophie (2007) Les discours de la presse quotidienne. Observer, analyser, comprendre. Paris: Presses Universitaires de France.

Myers, Greg (2003) Discourse studies of scientific popularization: Questioning the boundaries. Discourse Studies 5.2: 265-79.

Nabi, R.L., D.R. Ewoldsen. and F.D. Carpentier (2008) Subjective knowledge and fear appeal 
effectiveness: Implications for image design. Health Communication 23: 191-201.

Oliver, M.B., and J.K. Wooley (2011) Tragic and poignant entertainment. The gratifications of meaningfulness as emotional response. In K. Döveling, Ch. von Scheve, and E.A. Konijn (eds.), The Routledge Handbook of Emotions and Mass Media. London and New York: Routledge, pp.134-147.

Ortony, A., G..L. Clore, and A. Collins (1988) The Cognitive Structure of Emotions. Cambridge, UK: Cambridge University Press.

Raney, Arthur A. (2011) Media enjoyment as a function of affective dispositions toward and moral judgment of characters. In K. Döveling, Ch. von Scheve, and E.A. Konijn (eds.), The Routledge Handbook of Emotions and Mass Media. London and New York: Routledge, pp.166-178.

Raney, Arthur A. (2006) The psychology of disposition-based theories of media enjoyment. In J. Bryant, and P. Vorderer (eds.), Psychology of entertainment. Mahwah, NJ: Erlbaum, pp. 137-150.

Russell, James A. (1980) A circumflex model of affect. Journal of Personality and Social Psychology 39: 1161-78.

Santamaria, L., and G. Brunat (2012) Discurs televisiu i multimodalitat. In M. Bassols (ed.), La divulgació en els nous formats televisius. Bellaterrra: Publications de la Universitat Autònoma de Barcelona, pp. 133-152.

Santamaria, L., M. Bassols, and A.M. Torrent (2011) Television programs for teenagers and the use of multimodality in knowledge popularisation. Journalism and Mass Communication 1. 2: 79-87.

Scherer, Klaus R. (1998) Emotionsprozesse im Medienkontext: Forschungsillustrationen und Zukunftsperspectiven. Medienpsychologie 10.4: 276-293.

Scherer, Klaus R. (1988) Criteria for emotion-antecedent appraisal: A review. In V. Hamilton, G..H. Bower, and N.H. Frijda (eds.), Cognitive perspectives on emotion and motivation. Dordrecht: Kluwer, pp. 89-126.

Schmitz, B., and U. Lewandrowski (1993) Trägt das Fernsehen zur Regulierung von Stimmungen bei? Intraindividuelle Analysen zur "Mood Management". Hypothese auf der Grundlage eines dinamischtransaktionalen Modells. Medienpsychologie 5.1: 64-84.

Schwab, F., and C. Schwender (2011) The descent of emotions in media. Darwinian perspectives. In K. Döveling, Ch. von Scheve, and E.A. Konijn (eds.), The Routledge Handbook of Emotions and Mass Media. London and New York: Routledge, pp. 15-36.

Searle, John (1969) Speach Acts: An Essay on the philosophy of Language. Cambridge: Cambridge University Press.

Stotland, Ezra (1969) Exploratory investigations of empathy. In L. Berkowitz (ed.), Advances in experimental social psychology Vol. 4: 271-313.

Turner, Monique M. (2011) Emotion in persuasion and risk communication. In K. Döveling, Ch. von Scheve, and E.A. Konijn (eds.), The Routledge Handbook of Emotions and Mass Media. London and New York: Routledge, pp. 237-258.

Unz, Dagmar C. (2011) Effects of presentation and editing on emotional responses on viewers. In K. Döveling, C. von Scheve, and E.A. Konijn (eds.), The Routledge Handbook of Emotions and Mass Media. London and New York: Routledge, pp. 294-309.

Van Leeuwen, Theo (1991) Conjunctive structure in documentary film and television. Continuum 5.1: 76114. 
Vorderer, P., and S. Knobloch (2000) Conflict and suspense in drama. In D. Zillmann, and P. Vorderer (eds.), Media entertainment: The psychology of its appeal. Mahwah, NJ /London: Lawrence Erlbaum Associates, pp. 56-68.

Wirth, W., and H. Schramm (2005) Media and Emotions. Communication Research Trends. Centre for the Study of Communication and Culture. 24.3: 1-39. 〈http://cscc.scu.edu/trends/v24/v24_3.pdf>

Zillmann, Dolf (1996) The psychology of suspense in dramatic exposition. In P. Vorderer, W.J. Wulff, and M. Friedrichsen (eds.), Suspense: Conceptualizations, theoretical analyses, and empirical explorations. Mahwah, NJ: Lawrence Erlbaum Associates, pp 199-231.

Zillmann, Dolf (1998) Does tragic drama have redeeming value? Siegener Periodikum für Internationale Literaturwissenschaft 16: 1-11.

Zillmann, Dolf (1991) Empathy: Affect from bearing witness to the emotions of others. In J. Bryant, and D. Zillmann (eds.), Responding to the screen: Reception and reaction processes. Hillsdale, NJ: Lawrence Erlbaum Associates, pp. 135-168.

Zillmann, D., and J. Bryant (1975) Viewer's moral sanction of retribution in the appreciation of dramatic presentations. Journal of Experimental Social Psychology 11: 572-82.

Zillmann, D., and J.R. Cantor (1972) Directionality of transitory dominance as a communication variable affecting humor appreciation. Journal of Personality and Social Psychology 24: 191-198.

Zillmann, D., and J.R. Cantor (1977) Affective responses to the emotions of a protagonist. Journal of Experimental Social Psychology 13: 155-165.

MARGARIDA BASSOLS, teacher at the Faculty of Communication (Universitat Autònoma, Barcelona) and $\mathrm{Ph} . \mathrm{D}$. in Catalan Philology, has several publications of discourse analysis in the media and in political discourse (El llenguatge dels polítics). But her primary research is on pragmatics (Les claus de la pragmàtica) and functional variation (El colloquial dels mitjans de comunicació). At the present time she coordinates the Llengua i Mèdia group.

Address: Universitat Autònoma de Barcelona, Facultat de Ciències de la Comunicació, Edifici I, 08193 Bellaterra (Barcelona), Spain. E-mail: Margarida.bassols@uab.cat

ANNA CROS, teacher at the Faculty of Science Education (Universitat Autònoma, Barcelona) and Ph.D. in Catalan Philology, has specialized in the study of oral academic discourse. In this field, she has worked on the analysis of argumentative strategies used in classroom by university teachers, on teaching strategies used by expert teachers, and on the study of different language styles of university management. She is member of the Llengua i Mèdia group and she is working in discourse analysis in the media.

Address: Universitat Autònoma de Barcelona, Facultat de Ciències de la Comunicació, Edifici I, 08193 Bellaterra (Barcelona), Spain. E-mail: anna.cros@uab.cat

ANNA M. TORRENT, teacher at the Faculty of Communication (Universitat Autònoma, Barcelona), Ph.D. in Catalan Philology and member of the Llengua i Mèdia group, has focused her teaching and research activity on the language of the media and advertising. In these fields she has primarily studied language variation, the development of the coloquial fictional, the creation of neologisms and the strategies to adapt 


\section{Margarida Bassols, Anna Cros, and Anna M. Torrent}

discourse to the media context.

Address: Universitat Autònoma de Barcelona, Facultat de Ciències de la Comunicació, Edifici I, 08193

Bellaterra (Barcelona), Spain. E-mail: anna.torrent@uab.cat 